\title{
Synthesis of Nano-Scale Biopolymer Particles from Legume Protein Isolates and Carrageenan
}

\section{Indika Dilrukshi \\ Koralegedara๑, Charith \\ Aravinda Hettiarachchi*®) Batugahage Don Rohitha \\ Prasantha@ and Kuruppu \\ Mudiyanselage Swarna \\ Wimalasirio}

Department of Food Science and Technology, Faculty of Agriculture, University of Peradeniya, 20400 Peradeniya, Sri Lanka

Received: 7 March 2019 Accepted: 10 July 2020

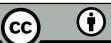

*Corresponding author:

Phone: +41768171355

E-mail:charithuop@yahoo.com

\section{SUMMARY}

Research background. Food proteins and polysaccharides can be used for the synthesis of nano-scale biopolymer particles with potential applications in the fields of food and pharmaceuticals. This study focuses on utilizing legume proteins for the production of biopolymer particles via regulation of their electrostatic interactions with carrageenan.

Experimental approach. Protein isolates were obtained from mung bean (Vigna radiata), cowpea (Vigna unguiculata) and black gram (Vigna mungo) and their protein profiles were determined. Next, these isolates were allowed to interact with carrageenan at $\mathrm{pH}=5.0-7.0$ to determine optimum conditions for obtaining nano-scale biopolymer particles. Selected biopolymer mixtures were then subjected to a heat treatment $\left(85^{\circ} \mathrm{C}\right.$ for $\left.20 \mathrm{~min}\right)$ to enhance the interactions among biopolymers.

Results and conclusion. Nano-scale biopolymer complexes were obtained at $\mathrm{pH}=6.5$. They were roughly spherical in shape with a majority having a diameter in the range of approx. 100-150 nm. Heating of the biopolymer mixtures increased the diameter of the biopolymer particles by approx. 2.5 -fold. In addition, their negative surface charge was increased, stabilizing them against aggregation over a broader $\mathrm{pH}$ range (4.0-7.0), enhancing their potential to be utilized in food matrices.

Novelty and scientific contribution. This study reports the applicability of mung bean, cowpea and black gram proteins for the synthesis of stable biopolymer particles. These biopolymer particles can be potentially used for the encapsulation and delivery of bioactive components.

Key words: biopolymer particles, protein-polysaccharide interactions, electrostatic complexes, legume proteins, carrageenan

\section{INTRODUCTION}

Formation of nano-scale particles from edible biopolymers has gained considerable interest due to their applicability in pharmaceuticals and processed foods as delivery agents of bioactive compounds via adsorption or encapsulation (1-5). Moreover, certain studies have shown that such particles can mimic rheological, optical and sensory properties of fat, enabling them to be used as fat replacers $(6,7)$.

Food proteins and anionic polysaccharides have become common candidates for the fabrication of these biopolymer particles, because they carry opposite charges at food related $\mathrm{pH}$ values, enabling them to form electrostatic complexes. The extent of electrostatic interactions can be regulated relatively easily by adjusting the $\mathrm{pH}$ and/or ionic strength of the interaction medium, enabling a higher degree of control $(8,9)$. At $\mathrm{pH}$ values below the isoelectric point (pl) of the proteins, where the proteins carry a net positive charge, extensive complex formation takes place between proteins and anionic polysaccharides resulting in a liquid coacervate phase or macroscopic aggregates, which usually result in a precipitate in the mixture (8). However, at pH values slightly above the $\mathrm{pl}$ of the proteins, where the proteins carry a net negative surface charge, they form soluble complexes with anionic polysaccharides due to the limited electrostatic interactions with positively charged sites still available on the protein surface $(9,10)$. Stability of these biopolymer particles against 
aggregation can be enhanced by increasing the ionic strength of the medium or their surface charge (11).

There are reports on the formation of biopolymer particles by electrostatic complexation between $\beta$-lactoglobulin and pectin (12-14), $\beta$-lactoglobulin and sodium alginate (15), lactoferrin and carrageenan (16), whey protein isolate and sodium alginate (17), sodium caseinate and gum Arabic (18), and gelatin and gum Arabic, cress seed gum and zedo gum $(19,20)$. However, only a few studies have been conducted to form biopolymer particles using plant proteins (21-23).

Due to the higher protein content in seeds (cereals, legumes and oil seeds; approx. $20-45 \% \mathrm{~m} / \mathrm{m})(24-26)$, they have become the popular choice among the sources of plant proteins. Seed proteins, based on their solubility, can be categorized into three major types, namely, albumins, globulins and prolamins (27). Globulins are the predominant type of protein found in a vast variety of legume seeds, and based on their sedimentation coefficients, they are further classified into $7 \mathrm{~S}$ vicilins and 11 S legumins $(28,29)$. In general, vicilins are trimeric proteins with a molecular mass of approx. $150 \mathrm{kDa}$ made with subunits of approx. $50 \mathrm{kDa}$. Legumins are made of six subunit pairs and each pair is made of approx. $20 \mathrm{kDa}$ and approx. 40 kDa subunits, which are linked via a disulfide bond (27). Thus, legumins have a higher molecular mass than vicilins.

Due to the vast array of potential applications of biopolymer particles, as stated above, it would be worthwhile to investigate different sources of legume proteins that can be used for this purpose. During this study, three legume varieties rich in proteins, namely, mung bean, cowpea and black gram were selected as the protein source for the formation of biopolymer particles. The main objectives of this study are to form biopolymer particles by manipulating electrostatic interactions between the selected legume proteins and carrageenan, and to study the effect of thermal treatment on the $\mathrm{pH}$ stability and morphology of fabricated biopolymer particles.

\section{MATERIALS AND METHODS}

\section{Materials}

Three types of legumes, namely, mung bean (Vigna radiata), cowpea (Vigna unguiculata) and black gram (Vigna mungo) were selected for this study. Mung bean variety MI6, cowpea variety MI35 and black gram variety MI1 were purchased from the seed farm of the Department of Agriculture, Pelwehera, Sri Lanka. All these seeds had been pre-cleaned and they were free of debris and foreign materials. A sample of carrageenan, predominantly of the iota class was obtained from Motha Confectionery Works (Pvt) Ltd., Colombo, Sri Lanka. Chemicals used for the extraction of proteins and determination of protein content were obtained from VWR International (Darmstadt, Germany) and Sigma-Aldrich, Merck (St. Louis, MO, USA). Chemicals used for gel electrophoresis were purchased from Promega Corporation (Madison, WI, USA) and MP Biomedicals (Irvine, CA, USA).

\section{Preparation of legume seed flour samples}

For the preparation of legume seed flour samples, approx. $200 \mathrm{~g}$ of respective seed varieties were ground using a high-speed mill with a removable metal sample cup (Stein M2; Steinlite Corporation, Atchison, KS, USA). Before milling, the removable metal cup (with the sample) was cooled by immersing in ice, and milling was performed in short intervals (approx. $5 \mathrm{~s}, 3-4$ times) to prevent heat accumulation that may cause denaturation of proteins. The ground seed samples were sieved using a 200- $\mu$ m mesh (Haver Analysensiebe, Oelde, Germany). Crude protein content of all the legume seed flour samples was determined by Kjeldahl method in triplicate (30). Nitrogen conversion factor used for the calculations was 5.6 (31). The protein mass fraction of the selected varieties of mung bean, cowpea and black gram was (26.6 \pm 0.9$),(25.4 \pm 0.1)$ and (26.9 \pm 0.9$) \%$, respectively.

Legume seed flour samples were then defatted by cold extraction to increase the efficiency of protein extraction. For the cold extraction, legume seed flour was mixed with hexane at a ratio of $50 \%(\mathrm{~m} / \mathrm{V})$ and stirred continuously at 150 rpm using a magnetic stirrer (SB 162; Stuart, Stone, UK) for $1.5 \mathrm{~h}$. Next, the hexane was carefully decanted, residue flour sample was spread on a muslin cloth and allowed to dry for $24 \mathrm{~h}$ in an air circulating fume hood to remove the remaining hexane. The obtained defatted legume seed flour (further in text: defatted flour) samples were stored at $4{ }^{\circ} \mathrm{C}$ in sealed containers until they were further used.

\section{Protein extraction}

Protein extraction was carried out according to the method described by Boye et al. (32). A dispersion (10\%, $\mathrm{m} / \mathrm{V}$ ) was prepared from each defatted flour and its $\mathrm{pH}$ was adjusted to 8.5 with $0.1 \mathrm{M} \mathrm{NaOH}$ using a pH meter (Ecosan pH5; Eutech, Selangor, Malaysia), which is calibrated daily before usage. The $\mathrm{pH}$ adjusted dispersion was stirred for $1 \mathrm{~h}$ at ambient temperature $\left((28 \pm 2){ }^{\circ} \mathrm{C}\right)$ using the magnetic stirrer, and then it was centrifuged at 2200xg for 15 min (CT-4D; Hitachi, Tokyo, Japan). The supernatant was obtained and its $\mathrm{pH}$ was adjusted to 4.6 using $0.1 \mathrm{M} \mathrm{HCl}$. Next, it was stirred for $1 \mathrm{~h}$ at ambient temperature and then it was centrifuged as mentioned earlier. The supernatant was discarded and the retentate was suspended in water. Next, the $\mathrm{pH}$ of the suspension was adjusted to 7.0 using $0.1 \mathrm{M} \mathrm{NaOH}$, and it was dialyzed against water for $48 \mathrm{~h}$ at $4{ }^{\circ} \mathrm{C}$ using a $3.5 \mathrm{kDa}$ molecular mass cut-off membrane. The dialyzed solution was then lyophilized (Lyotrap-Plus; LTE Scientific Ltd., Oldham, UK), and the obtained legume protein isolate (LPI) samples were stored at $4{ }^{\circ} \mathrm{C}$ in sealed containers until they were used.

\section{Estimation of protein yield}

Crude protein content of the defatted flour and LPI samples was measured using the Kjeldahl method (30) in triplicate. The percentage of protein yield from defatted legume seed flour (DLSF) was calculated using the following equation (33): 
$Y\left(\right.$ protein $=100 \cdot\left[m(\mathrm{LPl}) \cdot w\left(\right.\right.$ protein $\left._{\mathrm{LPI}}\right] /[m(\mathrm{DF})] \cdot w\left(\right.$ protein $\left._{\mathrm{DF}}\right] / 1 /$

where $Y$ (protein) is protein yield, $m(\mathrm{LPI})$ is mass of the obtained $\mathrm{LPI}, w$ (protein $_{\mathrm{LPI}}$ is protein mass fraction in the LPI, $m(\mathrm{DF})$ is mass of defatted flour and $w$ (protein) $)_{D F}$ is the mass fraction of proteins in the defatted flour. Mass of the flour sample taken for the determination of protein yield was $45.0 \mathrm{~g}$.

\section{Protein profiling of LPI samples}

Sodium dodecyl sulfate polyacrylamide gel electrophoresis (SDS-PAGE) was conducted to determine the molecular mass of the proteins and peptides present in the LPI samples (34). Electrophoresis was conducted using a non-gradient polyacrylamide gel cast in the laboratory, and it consisted of a 4 $\%$ stacking gel and a $12 \%$ resolving gel. Lyophilized LPI samples were dissolved in water to obtain $3 \%(\mathrm{~m} / \mathrm{V})$ solution, and then further diluted to $1: 2(V / V)$ with Tris- $\mathrm{HCl}(\mathrm{pH}=6.8)$ sample buffer, which contained $5 \%$ (V/V) $\beta$-mercaptoethanol. The samples were heated at approx. $95^{\circ} \mathrm{C}$ for $4 \mathrm{~min}$ in a water bath and an aliquot of $12 \mu \mathrm{L}$ from each sample was loaded into the wells of the polyacrylamide gel. A broad range molecular mass marker (10-225 kDa) was also loaded for the identification of molecular mass of the resulting sample bands. The gel was electrophoresed at $150 \mathrm{~V}$, and then it was stained with a solution of $0.2 \%(\mathrm{~m} / \mathrm{V})$ Coomassie brilliant blue dissolved in $10 \%(V / V)$ acetic acid and $40 \%(V / V)$ methanol for about an hour. Finally, the gel was destained using a solution of $5 \%(V / V)$ acetic acid and $20 \%(V / V)$ methanol for $24 \mathrm{~h}$.

\section{Preparation of LPI and carrageenan solutions}

LPI solutions ( 0.1 and $0.2 \%, m / V)$ were prepared by dissolving lyophilized LPI powders in water. The solutions were stirred for $30 \mathrm{~min}$ at ambient temperature for the complete hydration of the powders. A carrageenan solution $0.1 \%(\mathrm{~m} / \mathrm{V})$ was prepared by dissolving carrageenan in hot water. The solution was stirred for $30 \mathrm{~min}$ at $80^{\circ} \mathrm{C}$ to ensure complete hydration. Next, LPI and carrageenan solutions were centrifuged at $1100 \times g$ (CT-4D; Hitachi) for $15 \mathrm{~min}$ to remove any remaining insoluble materials and their $\mathrm{pH}$ was adjusted to 7.0 using $0.1 \mathrm{M} \mathrm{NaOH}$. The contents of LPI and carrageenan given in the text are not corrected for minor changes that can occur due to centrifugation and $\mathrm{pH}$ adjustment.

\section{Formation of biopolymer particles}

$\mathrm{LPI}$ and carrageenan solutions, 0.2 and $0.1 \%(\mathrm{~m} / \mathrm{V})$, respectively, at $\mathrm{pH}=7$, were mixed in equal volumes to allow interactions between legume proteins and carrageenan molecules. These mixtures were kept for $1 \mathrm{~h}$ at ambient temperature before they were subjected to further analysis. The $\mathrm{pH}$ of these mixtures was verified to be $7.0 \pm 0.2$. In order to manipulate the electrostatic interactions between the two biopolymers, the $\mathrm{pH}$ of the mixtures was gradually adjusted to values below 7.0 (up to $\mathrm{pH}=4.0$ ) using $0.1 \mathrm{M} \mathrm{HCl}$. These mixtures were also kept for $1 \mathrm{~h}$ at ambient temperature before they were subjected to further analysis.

\section{$\zeta$-Potential measurements}

For $\zeta$-potential measurements, aliquots $(10 \mathrm{~mL})$ obtained from $0.1 \%(\mathrm{~m} / \mathrm{V}) \mathrm{LPI}$ and carrageenan solutions at $\mathrm{pH}=7.0$ were adjusted to required $\mathrm{pH}$ values using $0.1 \mathrm{M} \mathrm{HCl}$, and they were kept for $1 \mathrm{~h}$ at ambient temperature. A dynamic light scattering device (Nano-ZS; Malvern Instruments, Malvern, UK) was used for the measurements. This device determines the surface charge by tracing the electrophoretic mobility of the constituents present in the solution under the applied potential difference, and then converts it to the $\zeta$-potential using the following equation (35):

$$
\mu=2 \varepsilon \cdot \zeta \cdot \frac{\mathrm{f}\left(k_{\mathrm{a}}\right)}{3 \eta}
$$

where $\mu$ is electrophoretic mobility, $\zeta$ is zeta potential, $\mathrm{f}\left(k_{\mathrm{a}}\right)$ is Henry's function (taken as 1.5 according to Smoluchowski approximation), $\varepsilon$ and $\eta$ are dielectric constant and viscosity of the medium, respectively, which were assumed to be the same as those of water due to the very diluted solutions used. The cell used for the measurements was filled with the sample with a syringe without trapping any air bubbles. In addition to individual biopolymer solutions, $\zeta$-potential of the mixtures made at $\mathrm{pH}=6.5$ was also measured before and after the heat treatment.

\section{Transmittance measurements}

Formation of biopolymer particles (large enough to scatter light) in the mixtures and their stability against precipitation at different $\mathrm{pH}$ values were monitored by measuring transmittance at $600 \mathrm{~nm}$ using a spectrophotometer (UV-1650; Shimadzu, Tokyo, Japan). No absorption occurs from the constituents present in the mixtures at the selected wavelength. A quartz cuvette with a path length of $1 \mathrm{~cm}$ was used for the measurements. Transmittance of individual biopolymer solutions at different $\mathrm{pH}$ values was also measured as control. The magnitude of reduction in transmitted intensity is considered to be inversely proportional to the level of interactions among biopolymers.

\section{Heat treatment of biopolymer particles}

A volume of $20 \mathrm{~mL}$ obtained from each mixture at $\mathrm{pH}=6.5$ was placed inside a screw-capped glass vial and heated in a water bath set at $85^{\circ} \mathrm{C}$ for $20 \mathrm{~min}$. The heat-treated mixtures were allowed to reach ambient temperature and they were diluted fivefold with water to ensure adequate transmittance of light. Aliquots $(10 \mathrm{~mL})$ obtained from these diluted mixtures were adjusted to different $\mathrm{pH}$ values between 4.0-7.0 with $0.1 \mathrm{M} \mathrm{HCl}$ or $0.1 \mathrm{M} \mathrm{NaOH}$ and kept for $1 \mathrm{~h}$ at ambient 
temperature. Transmittance of these heat-treated mixtures was measured as described above.

\section{Scanning electron microscopy}

Morphology of the biopolymer particles formed in the mixtures at $\mathrm{pH}=6.5$ before and after the heat treatment was observed using a scanning electron microscope (SEM; EVO; Carl-Zeiss, Cambridge, UK). An aliquot (10 $\mu \mathrm{L})$ pipetted out from each mixture was deposited onto a carbon tape that had been fixed to a SEM stub, and then it was dried using a stream of air. The dried samples were gold coated using a sputter coater (SE7620; Quorum, Lewes, UK) and observed using the microscope at $10 \mathrm{kV}$. Individual biopolymer solutions were also subjected to SEM as controls. Diameter of the biopolymer particles observed by SEM was measured using image J software, v. 1.52a (36), from which the pixels were converted to $\mathrm{nm}$ using the scale bar of each image.

\section{Statistical analyses}

Data acquisition was done on experiments carried out in triplicate. Significant differences between samples were assessed at a $p=0.05$ level by either one-way analysis of variance (ANOVA) or paired $t$-test. When ANOVA was performed, mean comparison was done using Tukey's test.

\section{RESULTS AND DISCUSSION}

\section{Protein yield of $L P I$ samples}

Table 1 presents the crude protein content of defatted flour and LPI samples, and the protein yield for each defatted flour. Crude protein content of LPI samples was approx. $90 \%(\mathrm{~m} / \mathrm{m})$ in the selected mung bean and cowpea varieties, while it was approx. $80 \%(\mathrm{~m} / \mathrm{m})$ in the black gram. Hence, the starting material, i.e. LPI samples used for the preparation of biopolymer particles had an acceptable level of purity $(\geq 80 \%, \mathrm{~m} / \mathrm{m})$.

Protein yield (recovery) from the defatted flour samples was between 50 and $65 \%(\mathrm{~m} / \mathrm{m})$. This could be due to the poor solubility of legume proteins, which leads to an incomplete extraction. High molecular mass proteins present in legumes (i.e. legumins) are known to exhibit a lower solubility due to their presence in hexamer form at $\mathrm{pH}$ values below 10 and above 3 (37).

Table 1. Crude protein mass fraction of defatted flour (DF) and legume protein isolate (LPI) samples

$\begin{array}{lccc}\text { Legume type } & w(\text { protein })_{D F} / \% & w(\text { protein })_{L P I} / \% & Y(\text { protein }) / \% \\ \text { Mung bean MI6 } & 26.5 \pm 0.7 & 87.3 \pm 0.3 & 52 \\ \text { Cowpea MI35 } & 25.7 \pm 0.8 & 89.6 \pm 0.5 & 63 \\ \text { Black gram MI1 } & 27.4 \pm 0.7 & 82.3 \pm 0.7 & 54\end{array}$

Protein mass fraction is shown as mean value \pm S.D. $(N=3)$. See Eq. 1 for the calculation of $Y$

\section{Molecular mass profiles of LPI samples}

An identical pattern of bands was observed in SDS-PAGE for the mung bean and cowpea LPI samples, with three intense bands near 55, 50 and $25 \mathrm{kDa}$, and a weaker band near $95 \mathrm{kDa}$ suggesting that both had a similar protein/peptide composition (Fig. S1). The bands observed at $\sim 55$ and 50 were attributed to the presence of monomeric subunits of vicilins (22). The band observed at $\sim 95 \mathrm{kDa}$ was assumed to be resulting from dimeric subunits of vicilins. The absence of a band near $150 \mathrm{kDa}$ for the trimeric vicilins and the low density observed of the band representing dimeric subunits suggested that trimeric vicilins present in mung bean and cowpea are prone to separate into their monomeric subunits, under the given extraction conditions. The $\sim 25 \mathrm{kDa}$ band might originate from post-translational proteolysis of monomeric subunits of vicilins (38).

Comparison of the band pattern of black gram LPI with mung bean and cowpea LPIs revealed that the molecular mass of the monomeric subunits of vicilins present in black gram LPI is distributed over a range of $\sim 45-55 \mathrm{kDa}$, with prominent bands at $\sim 45$ and $50 \mathrm{kDa}$. The weaker bands observed at $\sim 85-100 \mathrm{kDa}$ were assumed to be resulting from dimeric subunits of vicilins. The bands observed at $\sim 40 \mathrm{kDa}$ and in the range of $\sim 25-30 \mathrm{kDa}$ were believed to result from post-translational proteolysis of monomeric subunits of black gram vicilins. The density of these bands suggested that proteolytic processing of black gram vicilins takes place at an extensive level, compared to mung bean and cowpea vicilins. Similarly, a higher susceptibility to post-translational proteolytic processing has been observed with monomeric subunits of vicilins present in pea (Pisum sativum) (39).

Subunits of black gram legumins may have also contributed to the $\sim 40-\mathrm{kDa}$ band (as the electrophoresis was conducted under reducing conditions), but given their lower solubility under the extracted conditions, their presence in the black gram LPI was thought to be considerably lower than in vicilins. Moreover, no 40-kDa band was observed for the mung bean and cowpea LPI samples. Thus, all the prepared LPI samples were believed to mainly consist of vicilins. Lack of legumins explains the lower protein yield obtained from defatted flour samples (Table 1).

\section{$\zeta$-Potential of individual biopolymer solutions}

Fig. 1 shows how $\zeta$-potential of individual biopolymer solutions deviates with $\mathrm{pH}$. All the LPI samples showed a net positive charge at $\mathrm{pH}$ values below 4.5 and this was mainly attributed to the protonation of amine groups present in arginine and histidine amino acids, which have $\mathrm{p} K_{\mathrm{a}}$ values of 12.5 and 6.0, respectively (40). When the $\mathrm{pH}$ was adjusted above 4.5 , the LPI samples became negatively charged owing to the deprotonation of carboxyl groups present in aspartic and glutamic amino acids with $\mathrm{p} K_{\mathrm{a}}$ values of 3.9 and 4.1, respectively (40). Isoelectric point ( $\mathrm{pl}$ ) of the LPI samples was determined by interpolation, and their $\mathrm{pl}$ values varied within a narrow $\mathrm{pH}$ 


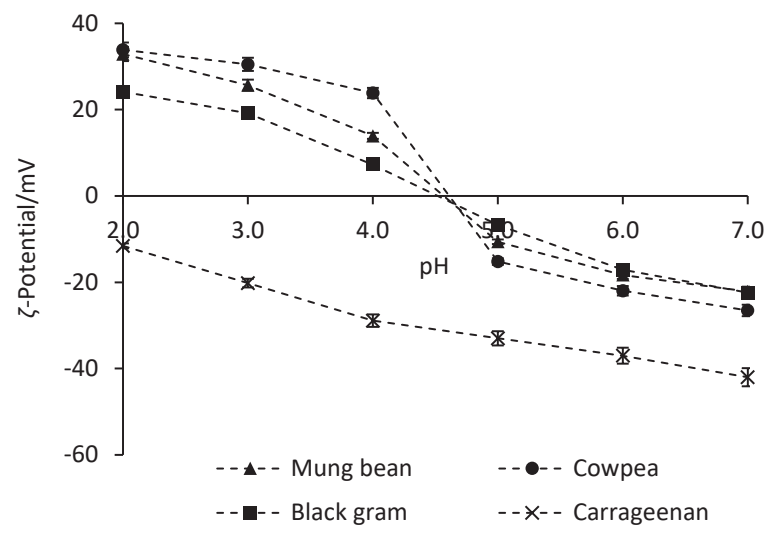

Fig. 1. ל-Potential of legume protein isolate samples and carrageenan solutions measured at different $\mathrm{pH}$ values. Biopolymer solutions of $0.1 \%(m / V)$ were used. Values are presented as mean \pm S.D. $(N=3)$

range of 4.5 to 4.7 (Fig. 1). The pl values obtained for the LPI samples were found to be comparable with those of chickpea, lupine and lentil seed proteins (41).

It should be noted that as a given LPI contains more than one type of protein molecules (Fig. S1), the measured $\zeta$-potentials indicate an average value derived from electrophoretic flow of all species preset in the LPI. The differences in the $\zeta$-potential observed among the three LPI samples at a given $\mathrm{pH}$ can also be attributed to the differences in the types of protein present and/or their relative amounts. Carrageenan remained negatively charged within the experimented $\mathrm{pH}$ range due to the presence of sulfate groups attached to galactose and 3,6-anhydro-D-galactose monomer units. Magnitude of the negative charge of carrageenan increased with increasing $\mathrm{pH}$, as the $\mathrm{pH}$ shift away from the $\mathrm{p} K_{\mathrm{a}}$ of sulfate groups (42).

\section{Electrostatic interactions between LPI samples and carrageenan}

In order to facilitate electrostatic complex formation between LPI samples and carrageenan, individual solutions at $\mathrm{pH}=7$ were mixed together, and then the $\mathrm{pH}$ of the mixtures was reduced step-wise up to $\mathrm{pH}=5$. A decrease of transmittance (or an increase of turbidity) in the mixtures resembles the formation of biopolymer particles, and the transmittance in all three mixtures was progressively decreased with the reduction of $\mathrm{pH}$ (Fig. S2). Occurrence of electrostatic interactions between oppositely charged groups during biopolymer complex formation has been recently demonstrated by Rajabi et al. (43) and Gharanjig et al. (20) via Fourier transform infrared (FTIR) spectroscopy. IR absorption peaks that represent (i) stretching of charged groups (e.g. carboxylates, sulfates), (ii) stretching of $\mathrm{C}=\mathrm{O}$ group in peptide bonds and (iii) stretching of $\mathrm{C}-\mathrm{N}$ and bending of $\mathrm{N}-\mathrm{H}$ bonds could shift or change their absorption intensity due to the formation of electrostatic complexes.
Reduction of $\mathrm{pH}$ results in an increased electrostatic potential difference between legume proteins and carrageenan, and this was evident by $\zeta$-potential measurements (Fig. 1). Thus, the level of electrostatic interactions between legume proteins and carrageenan increases with the reduction of $\mathrm{pH}$, resulting in more or larger biopolymer particles. The latter is more likely with the observed precipitation in the mixtures at lower $\mathrm{pH}$ values. Similar observations have been previously made by Hettiarachchi et al. (44). Transmittance of the individual solutions (i.e. three LPI samples and carrageenan) measured at the given $\mathrm{pH}$ values was always higher than those recorded for the mixtures (results not shown).

It should be noted that even though LPI samples showed a net negative $\zeta$-potential within the experimented $\mathrm{pH}$ range (5.0-7.0), proteins present in these samples still carry some positively charged (or protonated) amine groups (to a lesser amount). The number of protonated groups present in legume proteins will increase with decreasing $\mathrm{pH}$, facilitating more carrageenan molecules to electrostatically interact with them. Mixtures adjusted to $\mathrm{pH}=5$ appeared turbid to the naked eye and after an hour they precipitated. Mixtures adjusted to $\mathrm{pH}=6.0$ and 6.5 did not show any signs of precipitation within an hour. However, the mixtures at $\mathrm{pH}=6.0$ showed a precipitate after $24 \mathrm{~h}$, resulting in a significant increase $(p<0.05)$ in transmittance (Fig. $2 a)$. In comparison, no precipitation took place in the mixtures at $\mathrm{pH}=6.5$ after 24 $\mathrm{h}$, and their transmittance values at $24 \mathrm{~h}$ were comparable (no significant difference) to those recorded $1 \mathrm{~h}$ after their preparation (Fig. 2b). Based on these results, we postulated that the biopolymer complexes formed in the mixtures at $\mathrm{pH}=6.5$ are comparatively smaller in size and they carry adequate amount of charges on their surface (to repel each other) avoiding their aggregation and subsequent precipitation.

\section{Morphology of the biopolymer particles formed in selected mixtures}

Aliquots obtained from the mixtures adjusted to $\mathrm{pH}=6.5$ were subjected to SEM in order to observe the morphology of the biopolymer particles formed in those mixtures. SEM images were also obtained for the individual biopolymer solutions (three LPI samples and carrageenan) at the above $\mathrm{pH}$ value to serve as controls. No depositions were observed on the carbon tape for all the control samples (images not shown), confirming that the deposited particles observed for the mixtures resulted from the interactions between legume proteins and carrageenan, and they are not due to the self-aggregation of biopolymers.

The particles formed in all the selected mixtures appeared oblong or roughly spherical in shape (Fig. 3). When measuring the diameter of oblong biopolymer particles, the $x$-axis (i.e. short axis) was taken as the diameter. In each mixture, diameter of the biopolymer particles varied considerably over a broad range (Table 2), and this was attributed to the presence of different types of protein subunits in each LPI (Fig. S1). Availability of different types of protein subunits enables the formation of 


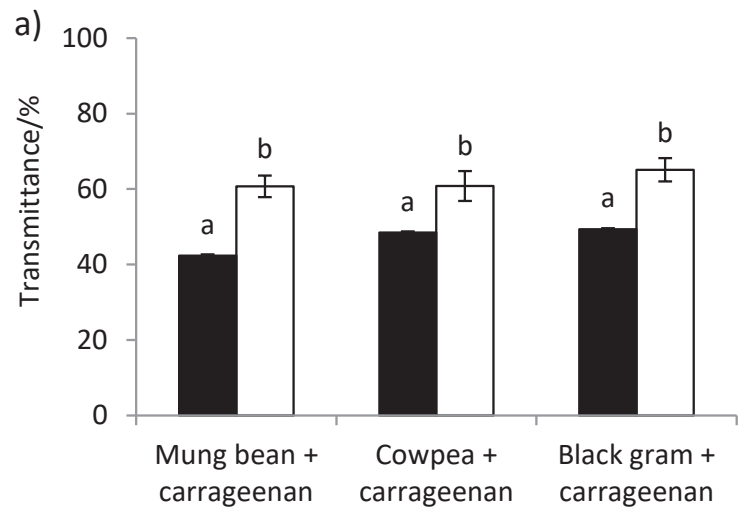

After $1 \mathrm{~h} \quad \square$ After $24 \mathrm{~h}$ b)

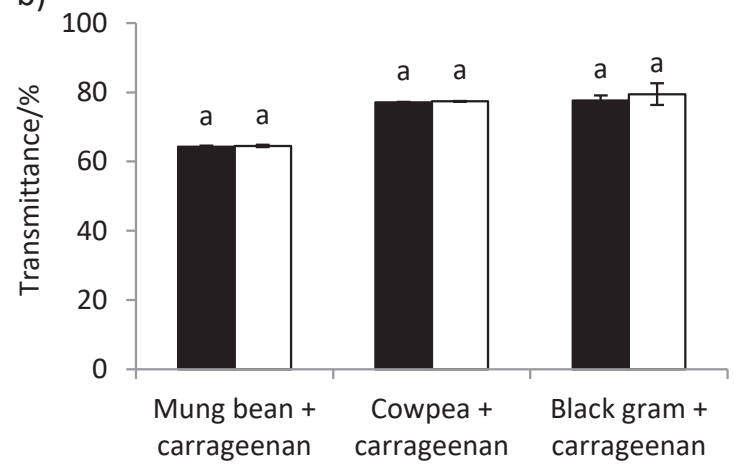

After $1 \mathrm{~h} \quad \square$ After $24 \mathrm{~h}$

Fig. 2. Transmittance of the mixtures measured 1 and $24 \mathrm{~h}$ after preparation: a) $\mathrm{pH}=6.0$, and b) $\mathrm{pH}=6.5$. Transmittance was measured at $600 \mathrm{~nm}$. Mixtures contain legume protein isolate $0.1 \%$ and carrageenan $0.05 \%(\mathrm{~m} / \mathrm{V})$. Values are presented as mean \pm S.D. ( $N=3)$. For a given type of mixture, values assigned with different superscript letters are significantly different $(p<0.05)$
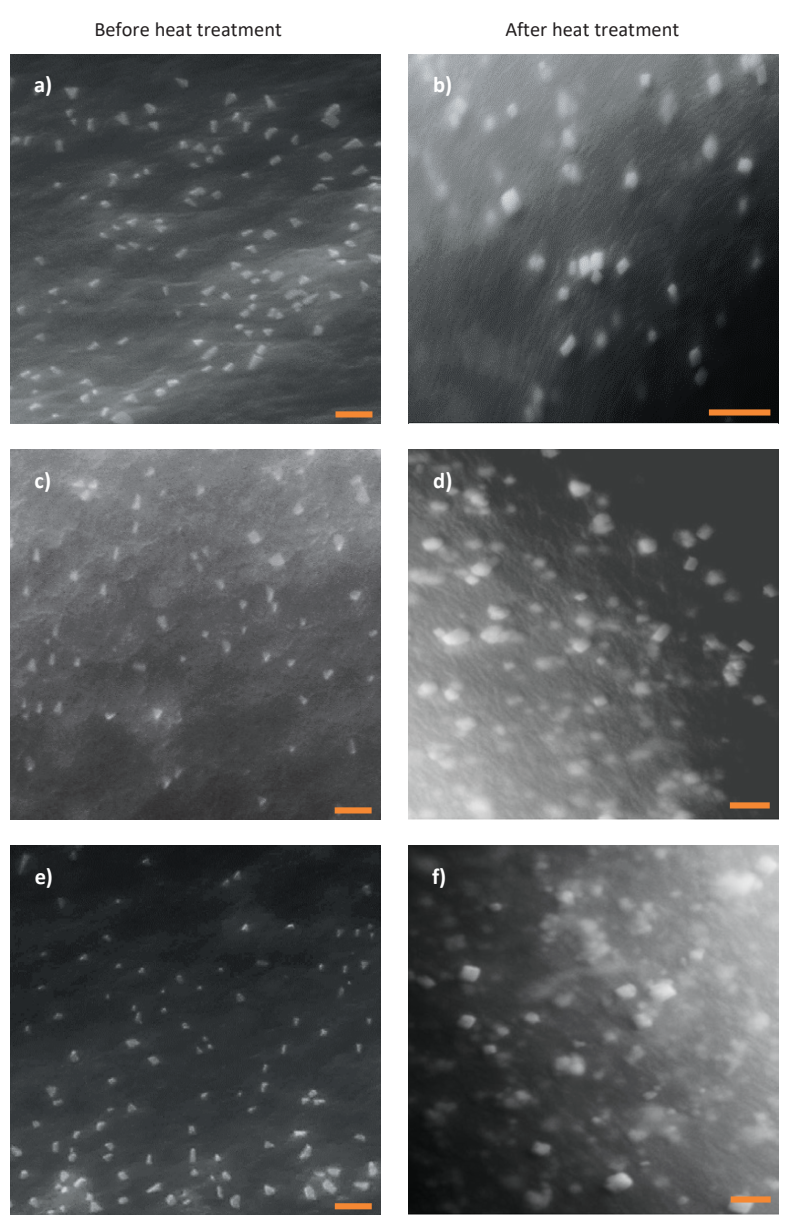

Fig. 3. SEM images of biopolymer particles present in the mixtures at $\mathrm{pH}=6.5$ before and after heat treatment $\left(85^{\circ} \mathrm{C}\right.$ for $\left.20 \mathrm{~min}\right)$ : a) and b) mung bean+carrageenan, c) and d) cowpea+carrageenan, e) and f) black gram+carrageenan. Mixtures contain legume protein isolate $0.1 \%$ and carrageenan $0.05 \%(\mathrm{~m} / \mathrm{V})$. Scale bars represent $2.0 \mu \mathrm{m}$

electrostatic complexes having different combinations of proteins with carrageenan, thus resulting in biopolymer particles of different sizes. Based on our observations, selection of an individual protein subunit or protein subunits within a narrow molecular mass range can be recommended to obtain biopolymer particles with a more uniform size.

Table 2. Average diameter of the biopolymer particles formed in legume protein isolate (LPI) and carrageenan mixtures at $\mathrm{pH}=6.5$ before and after the heat treatment

\begin{tabular}{lcc} 
& \multicolumn{2}{c}{$d / \mathrm{nm}$} \\
\cline { 2 - 3 } LPI with carrageenan & $\begin{array}{c}\text { Before heat } \\
\text { treatment }\end{array}$ & $\begin{array}{c}\text { After heat } \\
\text { treatment }\end{array}$ \\
Mung bean & $(117 \pm 32)^{\mathrm{b}}$ & $(345 \pm 62)^{\mathrm{a}}$ \\
Cowpea & $(138 \pm 40)^{\mathrm{ab}}$ & $(343 \pm 91)^{\mathrm{a}}$ \\
Black gram & $(154 \pm 59)^{\mathrm{a}}$ & $(374 \pm 117)^{\mathrm{a}}$
\end{tabular}

Diameter is given as mean value \pm S.D. $(N=50)$. Within a column, diameters with different superscript letters are significantly different $(p<0.05)$

\section{Effect of heat treatment on the biopolymer particles}

Heating the mixtures at $\mathrm{pH}=6.5$ above the denaturation temperature of the legume proteins led to an increase in the diameter of the biopolymer particles. SEM images obtained for the heat-treated mixtures are given in Fig. 3. For all three mixtures, the average diameter of the biopolymer particles after the heat treatment was approximately two and half-fold greater than their average diameter before the heat treatment (Table 2). This was attributed to the unfolding of the proteins present in biopolymer particles. During the unfolding process, one possibility is that the carrageenan molecules linked to the proteins may become detached, and the unfolded protein molecules will interact with each other resulting in larger biopolymer particles that are mainly composed of proteins $(12,13)$. Aggregation of unfolded protein molecules can take place via the formation of intermolecular disulfide bonds and increased hydrophobic interactions (45).

Alternatively, the unfolded protein subunits still partially attached to carrageenan molecules can aggregate (9), thus facilitating electrostatic attachment of more carrageenan molecules due to the exposure of new interaction sites, resulting 


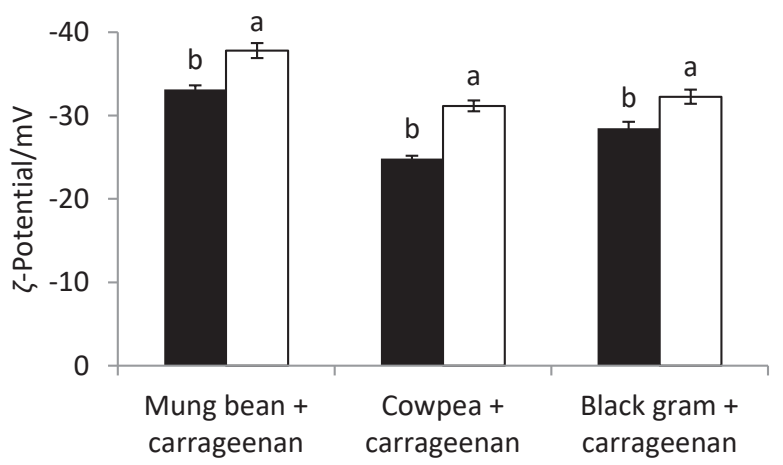

घ Before heat treatment $\quad \square$ After heat treatment

Fig. 4. $\zeta$-Potential of the biopolymer particles present in the mixtures at $\mathrm{pH}=6.5$ before and after heat treatment $\left(85^{\circ} \mathrm{C}\right.$ for $\left.20 \mathrm{~min}\right)$. Mixtures contain legume protein isolate $0.1 \%$ and carrageenan $0.05 \%(\mathrm{~m} / \mathrm{V})$. Values are presented as mean \pm S.D. $(N=3)$. For a given type of mixture, values with different superscript letters are significantly different $(p<0.05)$

in the formation of larger biopolymer particles with a higher number of both protein and carrageenan molecules. The significant increase $(p<0.05)$ in the net negative surface charge observed for the larger biopolymer particles after the heat treatment (Fig.4) suggests that the latter scenario is more plausible for the biopolymer particles formed during this study. If the biopolymer particles formed after the heat treatment are mainly composed of protein molecules, it is unlikely to observe an increase in their net negative surface charge.

After the heat treatment, the transmittance of a given mixture remained stable with the change of $\mathrm{pH}$, suggesting that biopolymer particles in the mixtures were less prone to aggregation even at $\mathrm{pH}$ values below the $\mathrm{pl}$ of the LPI (Fig. S3), enabling them to be used as stable colloidal systems in food applications. This was attributed to the increased negative surface charge of the biopolymer particles (Fig. 4), and it is possible that carrageenan molecules occupy a higher proportion of their surface, keeping them repelled from each other even at lower $\mathrm{pH}$ values. In addition, heat-induced Maillard reaction between free amino groups of LPIs and terminal reducing sugar moieties of carrageenan could lead to form covalently bound conjugates (46), increasing the structural stability of the biopolymer particles against $\mathrm{pH}$-induced dissociation and re-association. Formation of such covalent bonds in soy protein isolate-carrageenan biopolymer particles has been previously reported by Mao et al. (47) based on the modifications observed in $\mathrm{C}=\mathrm{O}$ and $\mathrm{C}-\mathrm{N}$ stretching absorption peaks of the IR spectrum. Further studies will be conducted on these LPI-carrageenan biopolymer particles in the future to elucidate their composition, structure and underlying interactions.

\section{CONCLUSIONS}

Mung bean, cowpea and black gram legume protein isolate (LPI) samples mainly consisted of monomeric ( $50 \mathrm{kDa})$ and dimeric ( 100 kDa) subunits, and post-translationally modified forms $(<50 \mathrm{kDa})$ of 75 vicilins. These LPI samples were capable of forming stable biopolymer particles with carrageenan at $\mathrm{pH}=6.5$ by limited electrostatic interactions. The average diameter of these biopolymer particles was in the range of 115-155 nm, and they had a negative surface charge of $\sim 28-$ $33 \mathrm{mV}$, which avoided their aggregation. Application of heat $\left(85^{\circ} \mathrm{C}\right.$ for $20 \mathrm{~min}$ ) increased the average diameter of the biopolymer particles ( 345-375 $\mathrm{nm}$ ), and this was attributed to the unfolding and aggregation of legume proteins. The heat-treated biopolymer particles had a higher negative surface charge at $\mathrm{pH}=6.5$ and they were resistant to aggregation over a broader $\mathrm{pH}$ range (4.0-7.0). It could be also suggested that formation of Maillard conjugates during the heat treatment may have led to increase the stability of the biopolymer particles.

\section{ACKNOWLEDGEMENTS}

Authors appreciate the support given by Mr Dhanushka Gamage (Department of Geology, University of Peradeniya) for SEM imaging and Ms Nuwanthi Katuwavila (Sri Lanka Institute of Nanotechnology) for zeta potential measurements.

\section{FUNDING}

This project was funded by the grant URG/2014/02/AG awarded by University of Peradeniya.

\section{SUPPLEMENTARY MATERIALS}

All supplementary materials are available at: www.ftb. com.hr.

\section{ORCID ID}

I.D. Koralegedara (D) https://orcid.org/0000-0002-7920-0130

C.A. Hettiarachchi $\odot$ https://orcid.org/0000-0001-6957-5740 B.D. Rohitha Prasantha @ https://orcid.org/0000-0003-3134-0756

K.M.S. Wimalasiri (1) https://orcid.org/0000-0002-3765-7212

\section{REFERENCES}

1. Chen L, Remondetto GE, Subirade M. Food protein-based materials as nutraceutical delivery systems. Trends Food Sci Technol. 2006;17(5):272-83.

https://doi.org/10.1016/j.tifs.2005.12.011

2. Emerich DF, Thanos CG. Targeted nanoparticle-based drug delivery and diagnosis. J Drug Target. 2007;15(3):163-83. https://doi.org/10.1080/10611860701231810

3. Assadpour E, Jafari SM, Maghsoudlou Y. Evaluation of folic acid release from spray dried powder particles of pectin-whey protein nano-capsules. Int J Biol Macromol. 2017;95:238-47.

\section{https://doi.org/10.1016/j.ijbiomac.2016.11.023}

4. Esfahani R, Jafari SM, Jafarpour A, Dehnad D. Loading of fish oil into nanocarriers prepared through gelatin-gum Arabic complexation. Food Hydrocoll. 2019;90:291-8. https://doi.org/10.1016/j.foodhyd.2018.12.044

5. Raei M, Shahidi F, Farhoodi M, Jafari SM, Rafe A. Application of whey protein-pectin nano-complex carriers for loading 
of lactoferrin. Int J Biol Macromol. 2017;105(Part 1):281-91. https://doi.org/10.1016/j.ijbiomac.2017.07.037

6. Lobato-Calleros C, Martínez-Torrijos O, Sandoval-Castilla O, Pérez-Orozco JP, Vernon-Carter EJ. Flow and creep compliance properties of reduced-fat yoghurts containing protein-based fat replacers. Int Dairy J. 2004;14(9):777-82.

https://doi.org/10.1016/j.idairyj.2004.02.012

7. Janhøj T, Ipsen R. Effect of pre-heat treatment on the functionality of microparticulated whey protein in acid milk gels. Milchwissenschaft. 2006;61(2):131-4.

8. de Kruif CG, Weinbreck F, de Vries R. Complex coacervation of proteins and anionic polysaccharides. Curr Opin Colloid Interface Sci. 2004;9(5):340-9.

https://doi.org/10.1016/j.cocis.2004.09.006

9. Schmitt C, Turgeon SL. Protein/polysaccharide complexes and coacervates in food systems. Adv Colloid Interface Sci. 2011;167(1-2):63-70.

https://doi.org/10.1016/j.cis.2010.10.001

10. de Kruif CG, Tuinier R. Polysaccharide protein interactions. Food Hydrocoll. 2001;15(4-6):555-63. https://doi.org/10.1016/S0268-005X(01)00076-5

11. Jones OG, McClements DJ. Stability of biopolymer particles formed by heat treatment of $\beta$-lactoglobulin/beet pectin electrostatic complexes. Food Biophysics. 2008;3(2):191-7. https://doi.org/10.1007/s11483-008-9068-5

12. Jones OG, Decker EA, McClements DJ. Formation of biopolymer particles by thermal treatment of $\beta$-lactoglobulinpectin complexes. Food Hydrocoll. 2009;23(5):1312-21.

https://doi.org/10.1016/j.foodhyd.2008.11.013

13. Jones OG, Lesmes U, Dubin P, McClements DJ. Effect of polysaccharide charge on formation and properties of biopolymer nanoparticles created by heat treatment of $\beta$-lactoglobulin-pectin complexes. Food Hydrocoll. 2010;24(4):374-83.

https://doi.org/10.1016/j.foodhyd.2009.11.003

14. Ghasemi S, Jafari SM, Assadpour E, Khomeiri M. Production of pectin-whey protein nano-complexes as carriers of orange peel oil. Carbohydr Polym. 2017;177:369-77.

https://doi.org/10.1016/j.carbpol.2017.09.009

15. Harnsilawat T, Pongsawatmanit R, McClements DJ. Characterization of $\beta$-lactoglobulin-sodium alginate interactions in aqueous solutions: A calorimetry, light scattering, electrophoretic mobility and solubility study. Food Hydrocoll. 2006;20(5):577-85.

https://doi.org/10.1016/j.foodhyd.2005.05.005

16. Peinado I, Lesmes U, Andrés A, McClements JD. Fabrication and morphological characterization of biopolymer particles formed by electrostatic complexation of heat treated lactoferrin and anionic polysaccharides. Langmuir. 2010;26(12):9827-34.

https://doi.org/10.1021/la1001013
17. Fioramonti SA, Perez AA, Aríngoli EE, Rubiolo AC, Santiago LG. Design and characterization of soluble biopolymer complexes produced by electrostatic self-assembly of a whey protein isolate and sodium alginate. Food Hydrocoll. 2014;35:129-36.

https://doi.org/10.1016/j.foodhyd.2013.05.001

18. Ye A, Flanagan J, Singh H. Formation of stable nanoparticles via electrostatic complexation between sodium caseinate and gum arabic. Biopolymers. 2006;82(2):121-33. https://doi.org/10.1002/bip.20465

19. Yang Y, Anvari M, Pan CH, Chung D. Characterisation of interactions between fish gelatin and gum arabic in aqueous solutions. Food Chem. 2012;135(2):555-61.

https://doi.org/10.1016/j.foodchem.2012.05.018

20. Gharanjig H, Gharanjig K, Hosseinnezhad M, Jafari SM. Development and optimization of complex coacervates based on zedo gum, cress seed gum and gelatin. Int J Biol Macromol. 2020;148:31-40.

https://doi.org/10.1016/j.ijbiomac.2020.01.115

21. Mirshahi T, Irache JM, Gueguen J, Orecchioni AM. Development of drug delivery systems from vegetal proteins: Legumin nanoparticles. Drug Dev Ind Pharm. 1996;22(8):841-6. https://doi.org/10.3109/03639049609065914

22. Elmer C, Karaca AC, Low NH, Nickerson MT. Complex coacervation in pea protein isolate-chitosan mixtures. Food Res Int. 2011;44(5):1441-6.

https://doi.org/10.1016/j.foodres.2011.03.011

23. Jun-xia X, Hai-yan Y, Jian Y. Microencapsulation of sweet orange oil by complex coacervation with soybean protein isolate/gum Arabic. Food Chem. 2011;125(4):1267-72. https://doi.org/10.1016/j.foodchem.2010.10.063

24. Shewry PR, Halford NG. Cereal seed storage proteins: Structures, properties and role in grain utilization. J Exp Bot. 2002;53(370):947-58. https://doi.org/10.1093/jexbot/53.370.947

25. Iqbal A, Khalil IA, Ateeq N, Sayyar Khan M. Nutritional quality of important food legumes. Food Chem. 2006;97(2):331-5. https://doi.org/10.1016/j.foodchem.2005.05.011

26. Liu C, Wang X, Ma H, Zhang Z, Gao W, Xiao L. Functional properties of protein isolates from soybeans stored under various conditions. Food Chem. 2008;111(1):29-37. https://doi.org/10.1016/j.foodchem.2008.03.040

27. Shewry PR, Napier JA, Tatham AS. Seed storage proteins: Structures and biosynthesis. Plant Cell. 1995;7(7):945-56. https://doi.org/10.2307/3870049

28. Kimura A, Fukuda T, Zhang M, Motoyama S, Maruyama N, Utsumi S. Comparison of physicochemical properties of $7 \mathrm{~S}$ and $11 \mathrm{~S}$ globulins from pea, fava bean, cowpea, and French bean with those of soybean-French bean $7 \mathrm{~S}$ globulin exhibits excellent properties. J Agric Food Chem. 2008;56(21):10273-9.

https://doi.org/10.1021/jf801721b 
29. Belitz HD, Grosch W, Schieberle P. Food chemistry. Heidelberg, Germany: Springer; 2009.

30. AOAC Method 97909. Proteins in grains. Gaithersburg, MD, USA: AOAC International; 2005.

31. Salo-Väänänen PP, Koivistoinen PE. Determination of protein in foods: Comparison of net protein and crude protein (N × 6.25) values. Food Chem. 1996;57(1):27-31. https://doi.org/10.1016/0308-8146(96)00157-4

32. Boye J, Zare F, Pletch A. Pulse proteins: Processing, characterization, functional properties and applications in food and feed. Food Res Int. 2010;43(2):414-31.

https://doi.org/10.1016/j.foodres.2009.09.003

33. Rahma EH, Dudek S, Mothes R, Görnitz E, Schwenke KD. Physicochemical characterisation of mung bean (Phaseolus aureus) protein isolates. J Sci Food Agric. 2000;80(4):477-83. https://doi.org/10.1002/(SICI)1097-0010(200003)80:4<477: :AID-JSFA553>3.0.CO;2-0

34. Laemmli UK. Cleavage of structural proteins during the assembly of the head of bacteriophage T4. Nature. 1970;227(5259):680-5. https://doi.org/10.1038/227680a0

35. Hunter RJ. Zeta potential in colloid science: Principles and applications. New York, NY, USA: Academic Press; 1981.

36. Rasband WS. ImageJ, v. 1.52a, National Institutes of Health, Bethesda, MD, USA; 2017. Available from: https://imagej. nih.gov/ij/.

37. Barać M, Čabrilo S, Pešić M, Stanojević S, Pavlićević M, Maćej O, Ristić N. Functional properties of pea (Pisum sativum, L.) protein isolates modified with chymosin. Int J Mol Sci. 2011;12(12):8372-87.

https://doi.org/10.3390/ijms12128372

38. Pedrosa C, Ferreira ST. Deterministic pressure-induced dissociation of vicilin, the 75 storage globulin from pea seeds: Effects of $\mathrm{pH}$ and cosolvents on oligomer stability. Biochemistry. 1994;33(13):4046-55.

https://doi.org/ 10.1021/bi00179a033

39. Rangel A, Domont GB, Pedrosa C, Ferreira ST. Functional properties of purified vicilins from cowpea (Vigna unguiculata) and pea (Pisum sativum) and cowpea protein isolate. J Agric Food Chem. 2003;51(19):5792-7.

https://doi.org/10.1021/jf0340052

40. Velíšek J. The chemistry of food. Oxford, UK: John Wiley and Sons; 2014.

41. Alsohaimy SA, Sitohy MZ, El-Masry RA. Isolation and partial characterization of chickpea, lupine and lentil seed proteins. World J Agric Sci. 2007;3(1):123-9.

42. Jones OG, Handschin S, Adamcik J, Harnau L, Bolisetty $S$, Mezzenga R. Complexation of $\beta$-lactoglobulin fibrils and sulfated polysaccharides. Biomacromolecules. 2011;12(8):3056-65.

https://doi.org/10.1021/bm200686r

43. Rajabi H, Jafari SM, Rajabzadeh G, Sarfarazi M, Sedaghati S. Chitosan-gum Arabic complex nanocarriers for encapsulation of saffron bioactive components. Colloids Surf A Physicochem Eng Asp. 2019;578:123644.

https://doi.org/10.1016/j.colsurfa.2019.123644

44. Hettiarachchi CA, Melton LD, Williams MAK, McGillivray DJ, Gerrard JA, Loveday SM. Morphology of complexes formed between $\beta$-lactoglobulin nanofibrils and pectins is influenced by the $\mathrm{pH}$ and structural characteristics of the pectins. Biopolymers. 2016;105(11):819-31.

https://doi.org/10.1002/bip.22917

45. Hoffmann MAM, van Mil PJJM. Heat-induced aggregation of $\beta$-lactoglobulin as a function of $\mathrm{pH}$. J Agric Food Chem. 1999;47(5):1898-905. https://doi.org/10.1021/jf980886e

46. de Oliveira FC, Coimbra JSR, de Oliveira EB, Zuñiga ADG, Rojas EEG. Food protein-polysaccharide conjugates obtained via the Maillard reaction: A review. Crit Rev Food Sci Nutr. 2016;56(7):1108-25.

https://doi.org/10.1080/10408398.2012.755669

47. Mao L, Pan Q, Hou Z, Yuan F, Gao Y. Development of soy protein isolate-carrageenan conjugates through Maillard reaction for the microencapsulation of Bifidobacterium longum. Food Hydrocoll. 2018;84:489-97.

https://doi.org/10.1016/j.foodhyd.2018.06.037 